\title{
SEASONAL ACTIVITY PATTERNS OF THE FROG, CRINIA SIGNIFERA (ANURA: MYOBATRACHIDAE), IN SOUTHERN TASMANIA, AUSTRALIA
}

\author{
by Bonnie Lauck, Roy Swain and Richard Bashford
}

(with one text-figure)

\begin{abstract}
Lauck, B., Swain, R. \& Bashford, R. 2005 (16:xii): Seasonal activity patterns of the frog, Crinia signifera (Anura: Myobatrachidae), in southern Tasmania, Australia. Papers and Proceedings of the Royal Society of Tasmania 139: 29-32. https://doi.org/10.26749/rstpp.139.29 ISSN 0080-4703. School of Zoology, University of Tasmania, GPO Box 252-05, Hobart, Tasmania 7001, Australia (BL;, RS); Forest Entomology, Forestry Tasmania, 79 Melville Street, Hobart, Tasmania, 7000, Australia (DB). *Author for correspondence.

We investigated the seasonal adaptations of the myobatrachid frog Crinia signifera Girard, 1863 in a commercial forest in sourhern Tasmania, Australia. Seasonal variation in activity patterns, body size and body condition was investigated. Although C. signifera does not hibernate over winter, activity levels are much reduced during this time. Females trapped in summer were smaller than those captured throughout the remainder of the year. We interpreted seasonal variation in the condition of captured frogs as an indication that breeding in spring and early summer is metabolically costly and fat stores are replenished by extensive foraging in summer. Fat stores accunulated in summer and autumn by males are used for body maintenance over winter and breeding in the following spring.
\end{abstract}

Key Words: body condition, Crinia signifera, frog, seasonal variation, Tasmania, activity.

\section{INTRODUCTION}

Anurans are ectothermic and their body temperatures are strongly correlated with ambient environmental temperatures. They also have a moist, permeable skin and are susceptible to desiccation (Blaustein et al. 1994). A trade-off between body temperature and water balance (Navas 1996) means that amphibian activity is often regulated by a combination of temperature and rainfall (Lemckert 2001). For example, the degree and duration of activity of the wood frog (Rana sylvatica LeConte, 1825) decreased with decreasing humidity (Bellis 1962).

With these physiological constraints, it is logical that seasonal environmental changes may regulate the activity patterns of amphibians. Variations in ambient temperature may also affect metabolism, thus affecting both body size and body condition. Ryser (1989), for example, concluded that weight loss in Rana temporaria Linnaeus, 1758 is caused by elevated metabolism. Reading \& Clarke (1995) found that, in addition to toad density at the breeding site, body condition of Bufo bufo (Linnaeus, 1758) was significantly correlated with air temperature.

Most studies investigating seasonal variation in activity, body size and body condition of temperate climate anurans have been carried out in the Northern Hemisphere (for example, Lamoureux et al. 2002, Morton 1981, Reading \& Clarke 1995). These studies have identified a general pattern in which migration to a breeding site occurs in spring and energy stores are rapidly depleted as a result of breeding. Fat storage is then replenished by a period of foraging activity and body condition is generally at its greatest at the end of autumn. These energy stores are then used during hibernation and the first few weeks of activity in the following spring.

Studies investigating seasonal variation in activity are carried out usually by trapping at breeding sites. As a consequence, studies that include the non-breeding fraction of the population are rare. Little is known also about the seasonal variation in activity of Australian amphibian populations. We investigated both this and the seasonal variations in body size, body condition and sex ratio in the anuran Crinia signifera in order to gain a greater biological understanding of the species at the southern limits of its latitudinal range in southern Tasmania, Australia.

\section{METHODOLOGY}

\section{Study Species}

Crinia signifera is widely distributed throughout Tasmania and south-eastern mainland Australia and is found in a wide range of habitats (Robinson 1996). This species breeds in both permanent and ephemeral sites; and in Tasmania breeding is limited to lentic systems (Littlejohn 2003, BL unpubl. data). In the southern forests of Tasmania breeding occurs predominantly between early spring and mid-summer with autumn breeding less common (BL unpubl. data). Metamorphosis occurs predominantly in January and February (BL unpubl. data).

\section{Study Area}

The study area is located at the Warra Long Term Ecological Research (LTER) site within the southern production forests of Tasmania. The site $\left(43^{\circ} 3\right.$ 'S; $\left.146^{\circ} 39^{\prime} \mathrm{E}\right)$ is approximately $60 \mathrm{~km}$ south of Hobart with an elevation range of $37-1260 \mathrm{~m}$ (Brown et al. 2001). Average annual temperature and rainfall are $7.9^{\circ} \mathrm{C}$ and $1477 \mathrm{~mm}$ respectively. Monthly variation in temperature is significant with mean diurnal temperatures of less than $4^{\circ} \mathrm{C}$ in winter and approximately $12^{\circ} \mathrm{C}$ in summer (www.warra.com 2005). Rain falls throughout the year but average monthly rainfall shows a strong winter bias and is at its lowest in late summer (Ringrose et al. 2001).

Trials were established at the Warra LTER to investigate alternative silvicultural practices (Hickey et al. 2001). One investigative sub-component of these silvicultural trials is to 
measure the responses of invertebrates. The specimens of $C$. signifera that we used in this study were opportunistically obtained as a by-catch from wet pitfall-ttaps used in this invertebrate study (see Bashford et al. 2001).

The following sampling strategy is summarised from Bashford et al. (2001). Twenty sites (located within five logging coupes) had been established at the site. Each site consisted of a $50 \mathrm{~m}$ transect with 10 pitfall traps. Pitfall traps were arranged in pairs, each separated by $1-2 \mathrm{~m}$, and consisted of a $9 \mathrm{~cm}$-diameter, $15 \mathrm{~cm}$-long PVC stormwater pipe set vertically into an augered hole in the soil. A 425 $\mathrm{mL}$ plastic cup (diameter $=9 \mathrm{~cm}$, 'Cast Away' brand) was set inside each pipe. Each cup was charged with $100 \mathrm{~mL}$ of either 33\% ethylene glycol (Castrol RadiCool) or 100\% ethylene glycol (Castrol). For further details tegarding the construction of pitfall traps refer to Bashford $e t$ al. (2001).

Sampling took place between September 1997 and December 2002. Trapping was undertaken in all seasons, with the number of trapping days totalling 2187 in summet, 982 in autumn, 331 in winter and 1064 in spring. Because sampling effort was unequal in different seasons and at different sites, captures were converted to capture rates (captures per trap day) in order to enable comparisons to be made.

Trapped frogs were killed and preserved by the ethylene glycol, and specimens wete stored in $70 \%$ ethanol after field collection. Each specimen was patted dry with paper towelling before its mass was measured using an electronic balance $( \pm 0.005 \mathrm{mg})$, and its snout-vent length (SVL) was measured using callipers $( \pm 0.05 \mathrm{~mm})$. The sex of adults was determined by morphological characteristics (males have grey, and females have white, colouring on the ventral surface of the chin). Individuals were classed as juveniles if the SVL was less than $20 \mathrm{~mm}$ (refer to growth curves in Lauck 2005). Because immature frogs of either sex also have grey ventral chin colouring (BL unpubl. data), juveniles were dissected to determine sex. Body condition was calculated as the cubed root of body mass $x \mathrm{SVL}^{-1}(3 \sqrt{\mathrm{g}} / \mathrm{mm}$, pers. comm. R. Alford).
Statistical analysis was undertaken using SPSS ${ }^{\mathrm{TM}} 10.0$ for Windows and $\alpha$ was set as 0.05 .

\section{RESULTS}

Fifty-two males and 71 females were captured. In addition there were 65 juveniles (including 28 that were too small for sex to be determined). The mean ( \pm SD) of SVL of females, males and juveniles was $26 \pm 3.9 \mathrm{~mm}, 23 \pm 2.4 \mathrm{~mm}$ and 15 $\pm 3.0 \mathrm{~mm}$, respectively. The mean mass ( \pm SD) of females, males and juveniles was $2.2 \pm 1.00 \mathrm{~g}, 1.4 \pm 0.50 \mathrm{~g}$ and 0.4 $\pm 0.02 \mathrm{~g}$, respectively.

Seasonal captures rates (fig. 1) indicate that frogs were most active within the forest litter during summer and least active during winter. Juveniles were most abundant in the landscape in summer. In winter, females were thtee times more likely to be trapped than males.

Because juveniles were given an arbitrary classification of having a SVL $<20 \mathrm{~mm}$, seasonal comparison of body size was not valid. One-way ANOVA showed that SVL did not vary with year of capture for females $\left(F_{4,61}=1.588, P\right.$ $=0.190$ ). Data from all years were pooled for females, and a one-way ANOVA was used to test the effect of season on SVL. SVL of females was lower in summer (mean and SEM: $25.82 \pm 0.546 \mathrm{~mm})$ than in autumn $(26.59 \pm 1.109$ $\mathrm{mm})$, winter $(30.55 \pm 1.281 \mathrm{~mm})$ and spring $(27.86 \pm$ $\left.0.810 \mathrm{~mm} ; \mathrm{F}_{3,61}=4.510, \mathrm{P}=0.007\right)$. Because the SVL of the males differed with the year of capture $\left(\mathrm{F}_{4,39}=4.721, \mathrm{P}\right.$ $=0.005$ ), a two-way ANOVA examining the effect of season and year was used to test the seasonal variation of SVL. SVL of the males did not differ with the season of capture $\left(\mathrm{F}_{3,39}\right.$ $=0.654, P=0.588)$. There was no significant interaction between year and season $\left(\mathrm{F}_{5,39}=1.321, \mathrm{P}=0.285\right)$.

Body condition could not be calculated for females because clutch mass was not measured separately ftom remaining body mass. One-way ANOVA showed that body condition did not vary with year of capture for both males and juveniles $\left(\mathrm{F}_{4,38}=1.692, \mathrm{P}=0.175\right.$ and $\mathrm{F}_{5,55}=1.846, \mathrm{P}$ $=0.121$, respectively). Data from all years were pooled and

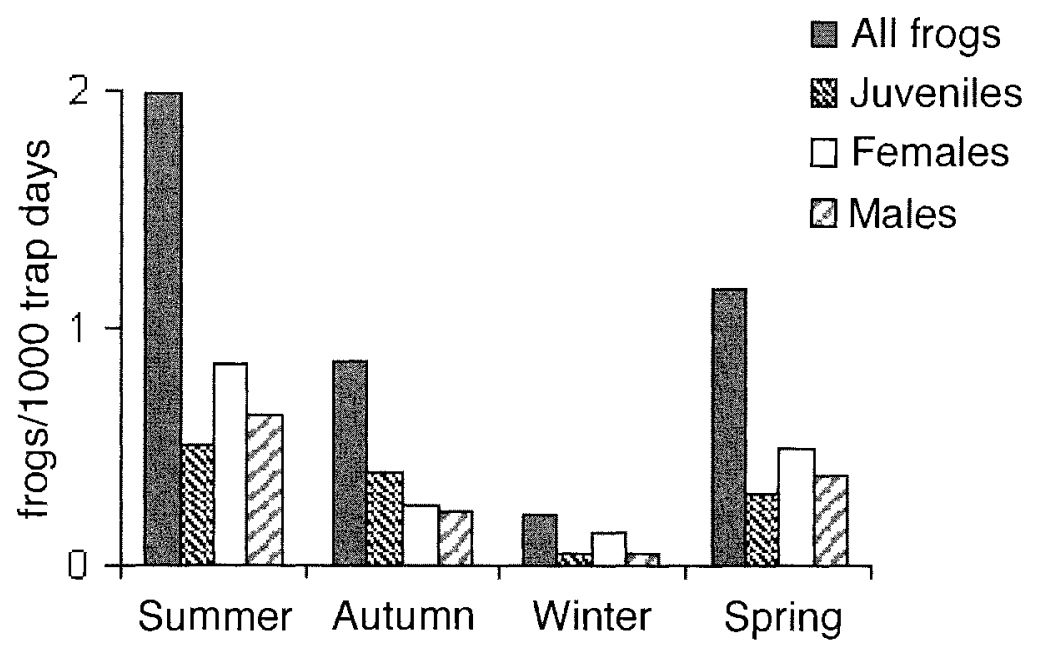

FIG. 1 - Seasonal variation in Crinia signifera capture rates (frogs per 1000 trap days) for all frogs, juveniles, females and males. 
a one-way ANOVA was used to test the effect of season on body condition. Body condition of adult males differed significantly between seasons $\left(\mathrm{F}_{3,38}=3.542, \mathrm{P}=0.024\right)$. Body condition was greatest in winter (mean and SEM: $0.45 \pm$ $0.024)$, followed by spring $(0.41 \pm 0.011)$, autumn $(0.39 \pm$ $.013)$ and summer $(0.38 \pm 0.008)$. Juvenile body condition did not vary with season $\left(\mathrm{F}_{3.55}=0.72, \mathrm{P}=0.544\right)$.

\section{DISCUSSION}

Most previous studies investigating seasonal adaptations of amphibians have been carried out by trapping at breeding sites over a number of breeding seasons (for example Mac Nally 1981, Reading \& Clarke 1995, Williamson \& Bull 1999). Studies incorporating the component of the population that is not actively involved in breeding are not common in the literature. Our study provides a rare opportunity to investigate just such an extended population of $C$. signifera in the southernmost part of its range in Tasmania, Australia.

Although higher capture rates of both males and females occurred during the summer it is interesting to note that females trapped in summer were smaller than in other seasons. It is likely that these individuals represent younger females that have a greater tendency to abstain from breeding and to maximise foraging in order to divert energy to further growth rather than reproduction (Lauck 2005). Such a trade-off between current reproduction and future reproductive success occurs because increased body size is often correlated with increased clutch size in female amphibians (Berven 1982, Lemckert \& Shine 1993, Ponsero \& Joly 1998).

Juveniles were also most commonly captured in summer, coinciding with the peak period of metamorphosis (BL unpubl. data). Although fewer juveniles were captured in other seasons in Tasmania, their body condition did not differ from those captured in summer.

Male body condition was at its greatest in winter, indicating that a preceding period of extended foraging had occurred. Unlike many anuran species of the Northern Hemisphere (Morton 1981, Reading \& Clarke 1995), C. signifera does not appear to hibernate over the winter, although activity levels are much reduced in comparison to other seasons. Depleted body condition in spring indicates that reduced activity in winter did not allow sufficient foraging to sustain male energy stores.

That breeding is metabolically costly is indicated by male body condition which was at its lowest in summer after the extended calling period. Lemckert \& Shine (1993) and Mac Nally (1981) also found that males of C. signifera lost significant energy reserves during periods of extended calling, despite the fact that it was possible for them to forage during this time.

The seasonal activity patterns of $C$. signifera in Tasmania show similar trends to those observed for other Northern Hemisphere temperate frogs. Our findings also concur well with those of other studies investigating the costs of reproduction in $C$. signifera breeding populations on mainland Australia.

\section{ACKNOWLEDGEMENTS}

Funding for this project was provided by the University of Tasmania and a Forestry Tasmania Warra small projects research grant. The support staff at the School of Zoology and staff at Forestry Tasmania provided a wealth of assistance throughout the course of this project. Our thanks also go to Murray Littlejohn and an anonymous reviewer for their extensive comments on an earlier draft of this manuscript. The project was conducted under University of Tasmania Ethics Permit No. A0006021. B. Lauck was supported by an Australian Postgraduate Award.

\section{REFERENCES}

Bashford, R., Taylor, R., Driessen, M., Doran, N. \& Richardson, A. 2001: Research on invertebrate assemblages at the Warra LTER Site. Tasforests 13: 109-118.

Bellis, E.D. 1962: The infuence of humidity on wood frog activity. The American Midland Naturalist 68: 139-148.

Berven, K.A. 1982: The genetic basis of altitudinal variation in the wood frog Rana syluatica. I. An experimental analysis of life history traits. Evolution 36: 962-983.

Blaustein, A.R., Wake, D.B. \& Sousa, W.P. 1994: Amphibian declines: judging stability, persistence, and susceptibility of populations to local and global extinctions. Conservation Biology 8: 60-71

Brown, M.J., Elliot, H.J. \& Hickey, J.E. 2001: An overview of the Warra long-term ecological research site. Tasforests 13: $1-8$.

Hickey, J.E., Neyland, M.G. \& Bassett, O.D. 2001: Rationale and design for the Warra silvicultural systems trial in wet Eucalytpus obliqua forests in Tasmania. Tasforests 13: $155-182$.

Lamoureux, V.S., Maerz, J.C. \& Madison, D.M. 2002 , Premigratory autumn foraging forays in the green frog, Rana clamitans. Journal of Herpetology 36: 245-254.

Lauck, B. 2005: Life history of the frog Crinia signifera in Tasmania, Australia. Australian Journal of Zoology 53: 21-27.

Lemckert, F. 2001: The influence of nicrometeorological factors on the calling activity of the frog Crinia signifera (Anura: Myobatrachidae). Australian Zoologist 31: 625-631.

Lemckert, F.L. \& Shine, R. 1993: Cost of reproduction in a population of the frog Crinia signifera (Anura: Myobatrachidae) from southeastern Australia. Journal of Herpetology 27: 420-425.

Littlejohn, M.J. 2003: Frogs of Tasmania. University of Tasmania, Hobart.

Mac Nally, R.C. 1981: On the reproductive energetics of the chorusing males: energy depletion profiles, restoration and growth in two sympatric species of Ranidella (Anura). Oecologia 51: 181-188.

Morton, M.L. 1981: Seasonal changes in total body lipid and liver weight in the Yosemite toad. Copeia 1981: 234-238.

Navas, C.A. 1996: Implications of microhabitat selection and patterns of activity on the thermal cology of high elevation neotropical anurans. Oecologia 108: 617-626.

Ponsero, A. \& Joly, P. 1998: Clutch size, egg survival and migration distance in the agile frog (Rana dalmatina) in a floodplain. Archiv fur Hydrobiologie 142: 343-352.

Reading, C.J. \& Clarke, R.T. 1995: The effects of density, rainfall and environmental temperature on body condition and fecundity in the common toad, Bufo bufo. Oecologia 102: 453-459.

Ringrose, C., Meyer, S., Bren, L.J. \& Neilson, W.A. 2001: Hydrology of small catchments in the Warra LTER Site: objectives and preliminary analysis. Tasforests 13: $31-44$. 
Robinson, M. 1996: A freld guide to frogs of Australia. Reed Books, Port Melbourne.

Ryser, J. 1989: Weight loss, reproductive output and the cost of reproduction in the common frog, Rana temporaria. Oecologia 78: 264-268.
Williamson, I. \& Bull, C.M. 1999: Life-history variation in a population of the Australian frog Ranidella signifera: seasonal changes in clutch parameters. Copeia 1999: $105-113$.

(accepted 27 June 2005) 